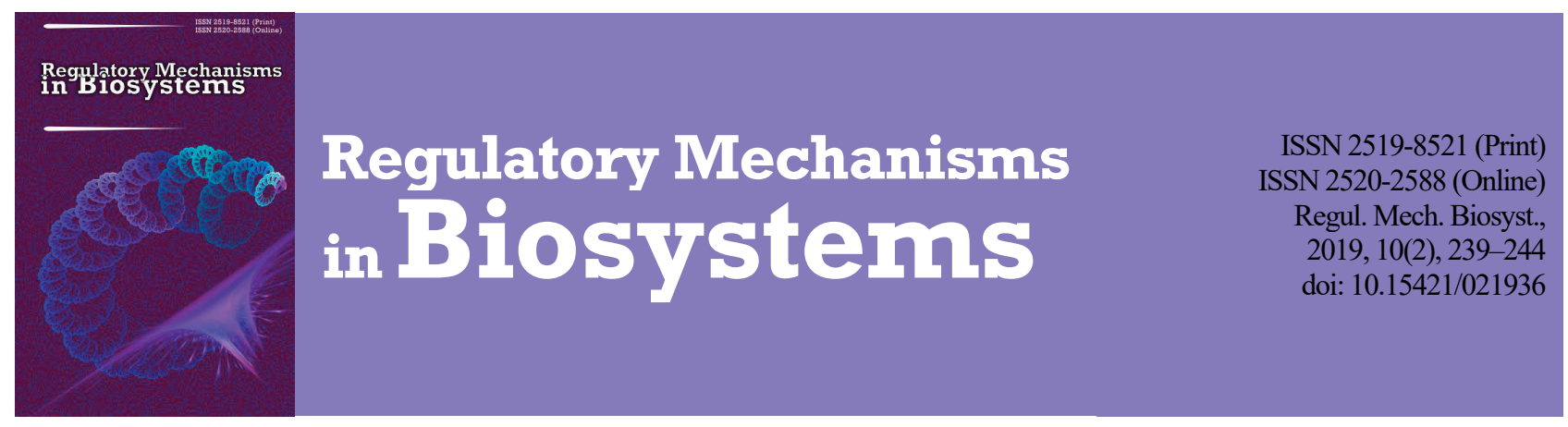

\title{
Depositing ability of stem of winter wheat varieties of different periods of selection
}

\author{
V. V. Morgun, G. A. Priadkina, O. V. Zborivska \\ Institute of Plant Physiology and Genetics of National Academy of Science of Ukraine, Kyiv, Ukraine
}

Article info
Received 06.04 .2019
Received in revised form
02.05.2019
Accepted 03.05 .2019

Institute of Plant Physiology and Genetics of National Academy of Science of Ukraine, Vasylkivska st., 31/17, Kyiv, 03022, Ukraine. Tel.: +38-068-123-62-92.

E-mail:

galpryadk@gmail.com

\author{
Morgun, V. V., Priadkina, G. A., \& Zborivska, O. V. (2019). Depositing ability of stem of winter wheat varieties of different pe- \\ riods of selection. Regulatory Mechanisms in Biosystems, 10(2), 239-244. doi:10.15421/021936
}

Adaptation of high-yielding winter wheat crops to changes in climatic conditions has great importance for food security of countries. The remobilization of stem assimilates for grain filling is one of the possible ways of increasing wheat yield in unfavourable environmental conditions. Field experiments in natural conditions with three old and three modern varieties of winter wheat were performed to compare depositing abilities of their stems. The objective of this study was a comparative analysis of the parameters of depositing capacity of stems of the main shoots for identification of the criteria for assessing grain productivity of winter wheat. The parameters of depositing capacity of the stem of the main shoots of three old winter wheat varieties $(1997,2003$, and 2008) and three modern ones (2013, 2014 and 2016) were studied in field conditions with natural conditions of water supply (Kyiv Oblast, Ukraine). During the period of formation of reproductive organs (April and May), the amount of precipitation, respectively, was only $17 \%$ and $68 \%$ of long-term values and average monthly air temperature was $3-4{ }^{\circ} \mathrm{C}$ higher than the climatic norm. We analyzed the variability of the parameters of depositing capacity of the stem of the main shoot and grain productivity of the ear of six wheat winter varieties which differed by time of selection. In unfavourable conditions during the period of formation of reproductive organs the modern winter wheat varieties had an $11 \%$ higher yield on average compared to the older ones. It was determined that the highest mass of grain from the ear of the main shoots (1.9-2.1 g) belonged to Odeska 267 variety, a drought-tolerant variety from earlier selection, and three modern varieties - Raihorodka, Prydniprovska and Darunok Podillia. It is demonstrated that these varieties also exceeded two old varieties (Podolianka and Yednist) by stem dry matter weight of main shoot at anthesis by $0.3-0.6 \mathrm{~g}$. The highest content of non-structural carbohydrates at this phase was observed in Odeska 267, Raihorodka and Darunok Podillia varieties (273$307 \mathrm{mg} / \mathrm{stem})$. Correlation analysis revealed the significant correlation between mass of grain from ear and dry matter of stem at anthesis and full ripeness, as well mass of grain from ear and the amount of non-structural carbohydrates at anthesis. Therefore, modern varieties of winter wheat and the drought-tolerant variety have higher yield, weight of dry matter of stem of the main shoot at anthesis and grain productivity of the ear, compared to old varieties. The results of this study indicate that the mass of dry matter of the stem of the main shoot at anthesis can be used as a marker of the grain productivity of winter wheat.

Keywords: Triticum aestivum L; dry matter weight; water soluble carbohydrates; grain productivity.

\section{Introduction}

Significant changes in weather conditions have been characteristic of the past decades. The global average air temperature in the period from 1961 to the $1990 \mathrm{~s}$ increased by $0.6^{\circ} \mathrm{C}$, and by the $2040 \mathrm{~s}$ this excess will already be $2{ }^{\circ} \mathrm{C}$ (Ciavarella et al., 2017; Avtaeva et al., 2019). The amount of precipitation has also decreased, compared with the 1980s (Lobell et al., 2011). Both of these factors contribute to the occurrence of droughts. Yields of important food crops - winter wheat - in drought conditions reduces on average by $21-32 \%$ (Zhang et al., 2018). Drought reduces the rate of photosynthesis and stomatal resistance, the assimilating surface area, causes the destruction of photosynthetic pigments and decreases the activity of antioxidant enzymes of thylakoid membranes of chloroplasts (Reynolds et al., 2015; Olsovska et al., 2016; Yan et al., 2016; Ouyang et al., 2017). Thus water deficit significantly reduces the amount of photoassimilates. There are two types of carbon sources of grain filling: the first is current photoassimilates, and the second is photoassimilates deposited in leaves, leaf sheaths, and stem metabolites. Therefore, an important feature of the adaptive ability of plants is the possibility to compensate losses of photosynthetic activity. In particular, it was shown that higher stem nonstructural (or water soluble) carbohydrate reserves compensated the loss of photosynthetic surface caused by influence of different factors (Esmaeilpour-Jahromi et al., 2012; Saeidi et al., 2012; Dodig et al., 2016).
Apart from the fact that carbohydrates contribute to grain ripening, they also contribute to plant osmotic regulation as osmolytes (Blum, 1998; Ehdaie et al., 2008). Therefore, the remobilization of assimilates from the stem, accumulated during vegetative growth in the form of watersoluble carbohydrates, is also an important additional source of grain filling (Reynolds et al., 2015; Nadia et al., 2017). The contribution of remobilized assimilates to grain depends on the genotype, organ and phase of plant development, as well as on the influence of unfavourable factors (Saeidi et al., 2012; Li et al., 2015; Zang et al., 2015; Ovenden et al., 2017). It is believed that the winter wheat varieties with high content of water-soluble carbohydrates can potentially have higher grain weight and yield (Dong et al., 2016).

Therefore, creating high-yielding, ecologically flexible winter wheat varieties with a high adaptive potential is important for preventing the negative effect of changes in climatic conditions on yield and ensuring food security of countries. One of the well-known methods for identifying the characteristics of high-yielding varieties is the comparative analysis of the parameters of contrast varieties by some indicators. Such analysis can help identify physiological patterns associated with high yields (Morgun et al., 2008). Since content of water-soluble carbohydrates in stems of different varieties of wheat can vary by 4-5 times (Ruuska et al., 2006; Esmaeilpour-Jahromi et al., 2012; Ma et al., 2014), research on genotypic differences by content of carbohydrates is important for searching selective criteria for increasing wheat yield. At the same time, 
since in the stem, in addition to carbohydrates, there are other substances, in particular, nitrogen-containing compounds which can also take part in hydrolysis and re-mobilization to grains, grain yield may also be associated with other indicators of stem depositing ability. The objective of this work was a comparative analysis of the parameters of depositing capacity of the stem of the main shoot for identifying the criteria of assessing grain productivity of winter wheat.

\section{Materials and methods}

The objects of the study were six varieties of winter wheat (Triticum aestivum L.), which differed by time of selective breeding. Three of them were registered 11-22 years ago (Odeska 267 - 1997, Podolianka 2003, and Yednist - 2008), and three are modern varieties (Darunok Podillia - 2013, Prydniprovska - 2014, and Raihorodka - 2016). The research was conducted in the 2017/2018 growing season on the grounds for testing varieties of winter wheat in the experimental field of the Institute of Plant Physiology and Genetics of National Academy of Science of Ukraine (50¹6' S, 30¹9' E; $197 \mathrm{~m}$ above sea level, Hlevaha urban settlement, Kyiv Oblast) in natural moisture conditions. The processes of the initiation of the reproductive organ formation took place in quite dry conditions and raised air temperature. In April 2018, an insignificant amount of precipitation (1-6 mm per day) fell, only three times in the month (Fig. 1). In May, precipitation was also lower than normal (68\%). From April to July, the average monthly air temperature, in general, exceeded the climatic norm (Fig. 2). In separate days of April and in the first decade of May, it was higher than the average multi-year values by $7-9^{\circ} \mathrm{C}$.

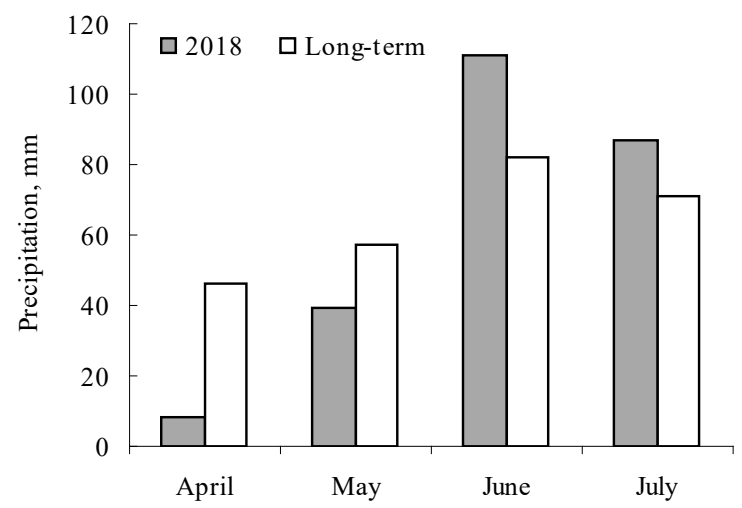

Fig. 1. Monthly precipitation, $\mathrm{mm}$, during the spring-summer winter wheat vegetation in 2018 and long-term (1881-2018) mean; the data of nearest meteorological station to the experimental fields (www.pogodaiklimat.ru/monitor)

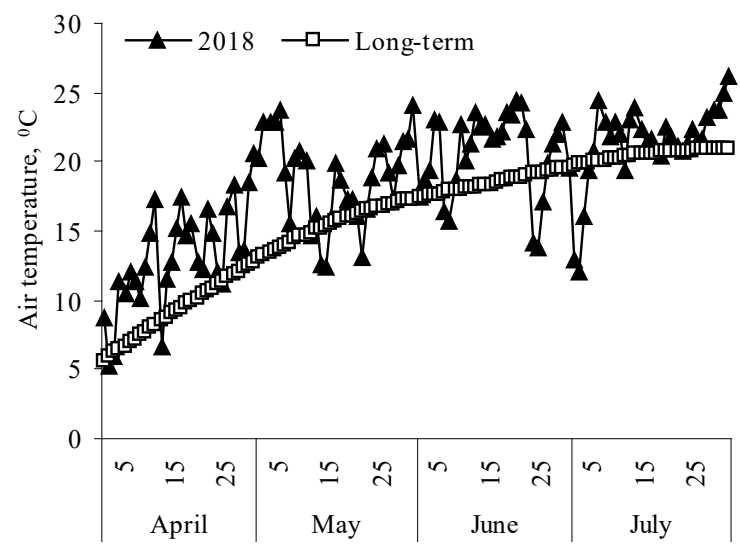

Fig. 2. Dynamics of daily mean air temperature $\left({ }^{\circ} \mathrm{C}\right)$ during the spring-summer winter wheat vegetation in 2018 and long-term mean: see Fig. 1

The seeding rate was 5.5-6.0 million grains per hectare. All varieties were sown on September 25th 2017, the area of each of four replications was $10 \mathrm{~m}^{2}$. The soil was light-grey, podzolized, light-loamy.
Agrotechnology and sowing management were those generally accepted for this crop in the forest-steppe agro-climatic zone (Morgun et al., 2015). During the growing season, $145 \mathrm{~kg}$ of nitrogen and $90 \mathrm{~kg}$ of phosphorus and potassium per hectare $\left(\mathrm{N}_{145} \mathrm{P}_{90} \mathrm{~K}_{90}\right)$ were added. The area of each replication was $10 \mathrm{~m}^{2}(1.5 \times 6.67 \mathrm{~m})$. Aboveground biomass and partitioning of the plant were determined by destructive sampling during anthesis (Zadoks GS 65) and at grain ripeness (Zadoks GS 92). Developmental stages were identified according to the external morphological characteristics of formed organs every 3-4 days (Zadoks et al., 1974). 25 main shoots were cut at ground level. The samples were separated into leaf, ear and stem (including leaf sheaths). The determination of biochemical parameters was carried out in the mean samples formed from 25 main shoots. For determining dry weight in each variety, separate organs were dried for 2 hours at $105^{\circ} \mathrm{C}$, and later they were dried completely to constant weight at $60^{\circ} \mathrm{C}$. At complete ripeness, parameters of the structure of grain productivity of the stem of the main shoot (weight of grain on the ear, number of grains in it, weight of 1000 grains, harvest index) was determined on 25 shoots. The yield was determined by direct combine harvesting method in 4 replications.

The content of non-structural (water-soluble) carbohydrates in the dry matter of the stem of the main shoot was determined at anthesis and full ripeness. For obtaining extract of carbohydrate, $0.5 \mathrm{~g}$ of air-dried stems was ground, and $50 \mathrm{~mL}$ of water was added and then underwent filtration. Then, $10 \mathrm{~mL}$ of the obtained filtrate and the copper-alkaline reagent $\left(\mathrm{CuSO}_{4} \cdot 5 \mathrm{H}_{2} \mathrm{O}, \mathrm{KJ}, \mathrm{KJO}_{3}\right)$ were poured into the test tubes and put into boiling water for $15 \mathrm{~min}$. After cooling, $5 \mathrm{~mL}$ of oxalic and sulfuric acid mixtures were added to the test tubes and the amount of copper precipitate was determined (Yermakov, 1972). After dissolving of the copper oxide, iodine precipitate was titrated using $0.01 \mathrm{~N}$ solution of sodium thiosulfate in the presence of $0.5 \mathrm{~mL}$ of a $0.5 \%$ of starch solution until the blue colour disappeared completely. The calculation of content of water-soluble carbohydrates was carried out according to Yermakov's formula (Yermakov, 1972). All analyses were performed in 4 replications.

The indirect evaluation of depositing ability of the stem was performed according to the content and amount of non-structural carbohydrates of the stem of main shoot stem at anthesis and full ripeness, and also dry weight during these phases and their difference at anthesis and full ripeness (Ruuska et al., 2006; Ehdaie et al., 2008; EsmaeilpourJahromi et al., 2012). Direct dry matter remobilisation (mg per stem) was evaluated by the changes in dry weight of stem (including leaf sheaths) over anthesis and complete ripeness (Foulkes at al., 2002; Kiriziy et al., 2014). The amount of non-structural carbohydrates was calculated as the product of their content in the dry matter of the stem and its weight (Kiriziy et al., 2014). Apparent efficiency of dry matter remobilisation, or in other words, the coefficient that demonstrates the contribution of carbohydrates accumulated in the stem from anthesis until complete ripeness to formation of grain productivity was calculated as a ratio of the difference in total amount of non-structural carbohydrates in the stem at anthesis and full ripeness to mass of grain from the ear (\%) (Papakosta \& Gagianas 1991; Kiriziy et al., 2014).

The data were statistically analyzed using ANOVA and criterion of reliable differences of Tukey's test for average values. The results are expressed as means and standard error $(x \pm \mathrm{SE})$. Differences between the data were considered reliable at $\mathrm{P}<0.05$.

\section{Results}

A high weight of grains per ear of the main shoot (1.9-2.1 g) of winter wheat plants which grew in drought conditions during the period of initiation of reproductive organs was observed in the old droughttolerant variety Odeska 267 and all three modern varieties (Table 1). The grain weight of varieties Podolianka and Yednist was less by $0.3-$ $0.6 \mathrm{~g}$. The variety Prydniprovska had the highest grains number per ear $(47.68 \pm 0.94)$ and the variety Podolianka had the lowest $(37.96 \pm 0.74)$. In other varieties, it ranged within close limits: from 42 to 44 . At the same time, varieties Odeska 267, Darunok Podillia and Raihorodka differed by the best grain filling: the weight of 1000 grains varied from 
49-54 g Also, the highest harvest index of the ear of the main shoot $(0.555)$ was observed in Raihgorodka variety.

\section{Table 1}

The yield components of main shoot ears of winter wheat varieties, released at different times $(\mathrm{x} \pm \mathrm{SE}, \mathrm{n}=25)$

\begin{tabular}{lcccc}
\hline \multicolumn{1}{c}{ Variety } & $\begin{array}{c}\text { Grain weight, } \\
\text { g per ear }\end{array}$ & $\begin{array}{c}\text { Weight of } 1000 \\
\text { grains, g }\end{array}$ & $\begin{array}{c}\text { Grains number, } \\
\text { grains/ear }\end{array}$ & $\begin{array}{c}\text { Harvest index } \\
(H I)\end{array}$ \\
\hline Odeska 267 & $1.874 \pm 0.039^{\mathrm{a}}$ & $49.58 \pm 0.68^{\mathrm{a}}$ & $41.76 \pm 0.57^{\mathrm{a}}$ & $0.533 \pm 0.006^{\mathrm{a}}$ \\
Podolianka & $1.589 \pm 0.040^{\mathrm{b}}$ & $46.22 \pm 0.81^{\mathrm{b}}$ & $37.96 \pm 0.74^{\mathrm{b}}$ & $0.527 \pm 0.005^{\mathrm{a}}$ \\
Yednist & $1.507 \pm 0.066^{\mathrm{b}}$ & $37.22 \pm 0.51^{\mathrm{c}}$ & $44.36 \pm 1.53^{\mathrm{c}}$ & $0.504 \pm 0.005^{\mathrm{b}}$ \\
Darunok Podillia & $2.125 \pm 0.055^{\mathrm{c}}$ & $54.42 \pm 0.64^{\mathrm{d}}$ & $43.32 \pm 0.92^{\mathrm{ac}}$ & $0.537 \pm 0.005^{\mathrm{a}}$ \\
Prydniprovska & $1.976 \pm 0.072^{\mathrm{a}}$ & $45.71 \pm 1.10^{\mathrm{b}}$ & $47.68 \pm 0.94^{\mathrm{d}}$ & $0.545 \pm 0.006^{\mathrm{a}}$ \\
Raihorodka & $1.900 \pm 0.077^{\mathrm{a}}$ & $48.59 \pm 1.27^{\mathrm{a}}$ & $42.96 \pm 1.01^{\mathrm{ac}}$ & $0.555 \pm$ \\
& & & & $0.010^{\mathrm{ac}}$ \\
\hline
\end{tabular}

Note: on each column means followed the same letters are not significantly different at $\mathrm{P}<0.05$.

The highest content of non-structural carbohydrates in stems of the main shoot at anthesis (23.3-23.6\%) were observed in varieties Odeska 267, Darunok Podillia and Raihorodka, the smallest content was in the Yednist variety (18.7\%) (Fig. 3a). At full ripeness, their content in the varieties Yednist and Prydniprovska (4.6-4.8\%) remained higher than in the other varieties (Fig. 3b).

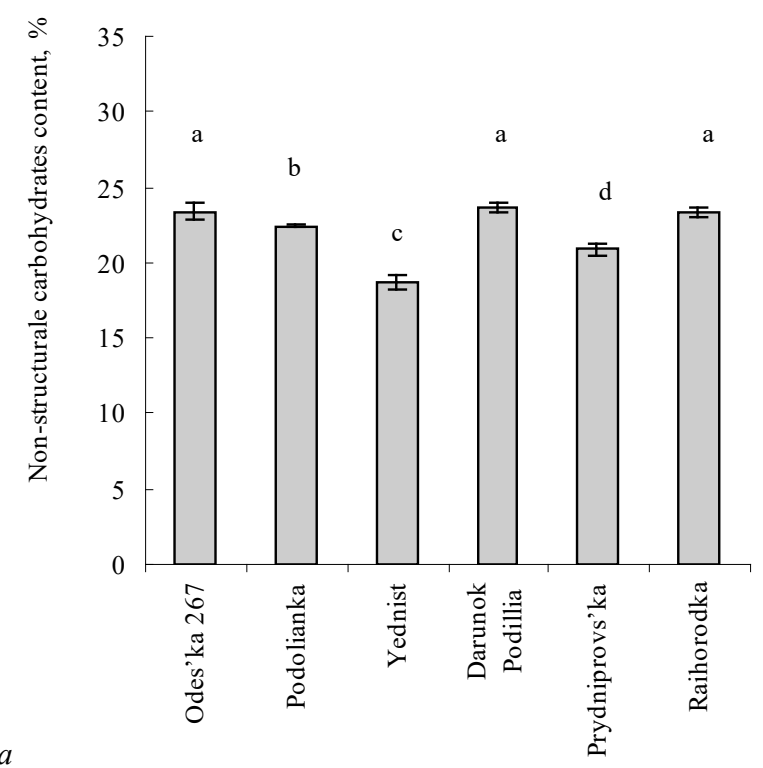

$a$

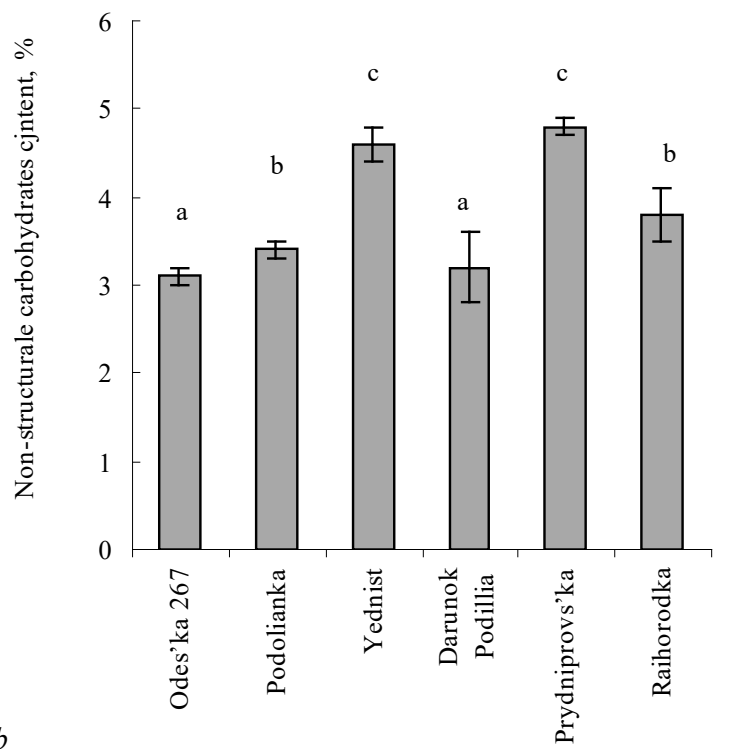

Fig. 3. Non-structural carbohydrates contents in main shoots stem of winter wheat varieties differed in time of selection at anthesis $(a)$ and full ripeness $(b): \mathrm{x} \pm \mathrm{SE} ; \mathrm{n}=4$ (analytical replication); means followed the same letters are not significantly different at $\mathrm{P}<0.05$
At anthesis, the modern variety Darunok Podillia had the highest dry weight of the main shoot (Table 2). In comparison with this, other varieties had a smaller dry weight of stem of the main shoots: by $10 \%$ less on average in varieties Odeska 267 and Raihorodka, by $18-25 \%$ less in Podolianka and Prydniprovska varieties and by $56 \%$ less in Yednist variety. At full ripeness, the mass of dry matter of stem of the main shoots in the three modern varieties and in old variety Odeska 267 was on average by $23 \%$ higher than that of Podolianka and Yednist varieties. The difference of dry weight of the stem of the main shoot, which characterizes the outflow of assimilates from the stem to the ear during the period between anthesis and complete ripeness, ranged from 419-445 mg in varieties Darunok Podillia and Raihorodka, 320-381 $\mathrm{mg}$ in varieties Odeska 267, Podolanka and Prydniprovska, and the lowest was in Yednist variety.

Table 2

Stem dry matter weight of the main shoots of winter wheat varieties, released at different times, at anthesis and full ripeness $(\mathrm{x} \pm \mathrm{SE}, \mathrm{n}=25)$

\begin{tabular}{|c|c|c|c|}
\hline \multirow[t]{2}{*}{ Variety } & \multicolumn{2}{|c|}{$\begin{array}{l}\text { Stem dry matter weight } \\
\text { of the main shoots, mg }\end{array}$} & \multirow{2}{*}{$\begin{array}{l}\text { Stem weight loss } \\
\text { between anthesis } \\
\text { and maturity, mg }\end{array}$} \\
\hline & at anthesis & at full ripeness & \\
\hline Odeska 267 & $1187 \pm 35^{\mathrm{a}}$ & $806 \pm 25^{\mathrm{a}}$ & $381 \pm 49^{\mathrm{a}}$ \\
\hline Podolianka & $1044 \pm 21^{b}$ & $687 \pm 17^{\mathrm{b}}$ & $358 \pm 27^{\mathrm{a}}$ \\
\hline Yednist & $832 \pm 43^{c}$ & $549 \pm 22^{c}$ & $283 \pm 54^{\mathrm{ab}}$ \\
\hline Darunok Podillia & $1301 \pm 36^{d}$ & $856 \pm 37^{\mathrm{a}}$ & $445 \pm 54^{\mathrm{ac}}$ \\
\hline Prydniprovska & $1103 \pm 23^{\mathrm{e}}$ & $783 \pm 21^{\text {ad }}$ & $320 \pm 31^{\mathrm{a}}$ \\
\hline Raihorodka & $1171 \pm 23^{\mathrm{a}}$ & $751 \pm 20^{\text {ad }}$ & $419 \pm 31^{\mathrm{ac}}$ \\
\hline
\end{tabular}

Note: see Table 1.

The amount of non-structural carbohydrates in the stem of the main shoot of modern winter wheat varieties at anthesis varied from 230 to $307 \mathrm{mg}$, that of old varieties - from 156 to $278 \mathrm{mg}$, and at full ripeness, resp., it ranged from $23-25$ and $27-38 \mathrm{mg}$ (Table 3). The highest remobilization of carbon accumulated since anthesis until full ripeness was observed in the modern variety Darunok Podillia (279.6 $\pm 8.7 \mathrm{mg} / \mathrm{stem})$, the varieties Odeska 267 and Raihorodka had slightly lower difference (resp., $252.7 \pm 8.4$ and $244.2 \pm 5.4 \mathrm{mg}$ ), and the lowest difference was observed in Yednist variety $(130.3 \pm 8.4)$. The higher difference in the amount of non-structural carbohydrates during the period from anthesis to complete ripeness indicates presence of a larger pool of assimilates deposited in the stem, which can be used for grain filling.

Table 3

Amount of non-structural carbohydrates in the main stem of winter wheat varieties, released at different times, at anthesis and full ripeness and the difference in their amount in these phases $(\mathrm{x} \pm \mathrm{SE}, \mathrm{n}=25)$

\begin{tabular}{|c|c|c|c|}
\hline \multirow{2}{*}{ Variety } & \multicolumn{2}{|c|}{$\begin{array}{c}\text { Amount of non-structural } \\
\text { carbohydrates of the main shoots, } \mathrm{mg}\end{array}$} & \multirow{2}{*}{$\begin{array}{l}\text { Amount of stem non- } \\
\text { structural carbohydrates } \\
\text { loss between anthesis } \\
\text { and maturity, mg }\end{array}$} \\
\hline & at anthesis & at full ripeness & \\
\hline Odes'ka 267 & $277.7 \pm 8.1^{\mathrm{a}}$ & $25.0 \pm 0,8^{\mathrm{a}}$ & $252.7 \pm 8.4^{\mathrm{a}}$ \\
\hline Podolianka & $233.9 \pm 4.6^{b}$ & $23.3 \pm 0.8^{\mathrm{a}}$ & $210.6 \pm 4.7^{b}$ \\
\hline Yednist & $155.6 \pm 8.0^{\mathrm{c}}$ & $25.3 \pm 1.0^{\mathrm{a}}$ & $130.3 \pm 8.4^{c}$ \\
\hline Darunok Podillia & $307.0 \pm 8.5^{\mathrm{d}}$ & $27.4 \pm 1.2^{\mathrm{ab}}$ & $279.6 \pm 8.7^{\mathrm{d}}$ \\
\hline Prydniprovs'ka & $230.4 \pm 4.7^{b}$ & $37.6 \pm 1.0^{\mathrm{c}}$ & $192.9 \pm 4.8^{\mathrm{e}}$ \\
\hline Raihorodka & $272.7 \pm 5.3^{\mathrm{a}}$ & $28.5 \pm 0.8^{\mathrm{bd}}$ & $244.2 \pm 5.4^{\mathrm{a}}$ \\
\hline
\end{tabular}

Note: see Table 1.

Indeed, the relative contribution of nonstructural carbohydrates to the weight of grain main stem of four varieties of winter wheat with their higher difference was greater (about 13\%) than for two varieties with a smaller difference (9-10\%) (Fig. 4).

Under unfavourable conditions during the period of formation of reproductive organs, the modern variety Raihorodka had the highest yield $\left(0.875 \pm 0.021 \mathrm{~kg} / \mathrm{m}^{2}\right)$. Its grain yield was higher by $7-9 \%$ than in the other two modern varieties and by $10-25 \%$ compared to the varieties of earlier selection (Table 4). On average, in such conditions, the modern winter wheat varieties had higher yield $\left(0.830 \pm 0.023 \mathrm{~kg} / \mathrm{m}^{2}\right)$ than the older ones $\left(0.731 \pm 0.037 \mathrm{~kg} / \mathrm{m}^{2}\right)$. 
In order to determine whether the difference in grain yield of the ear of the main shoot of the studied varieties was related to the parameters of depositing capacity of the stem, the correlation between them was analyzed. Significant correlation between the weight of grains per ear and the amount of non-structural carbohydrates during anthesis, as well as the dry weight of stem at anthesis and at full ripeness was determined in plants affected by the drought during initiation of the reproductive organs (Table 5).

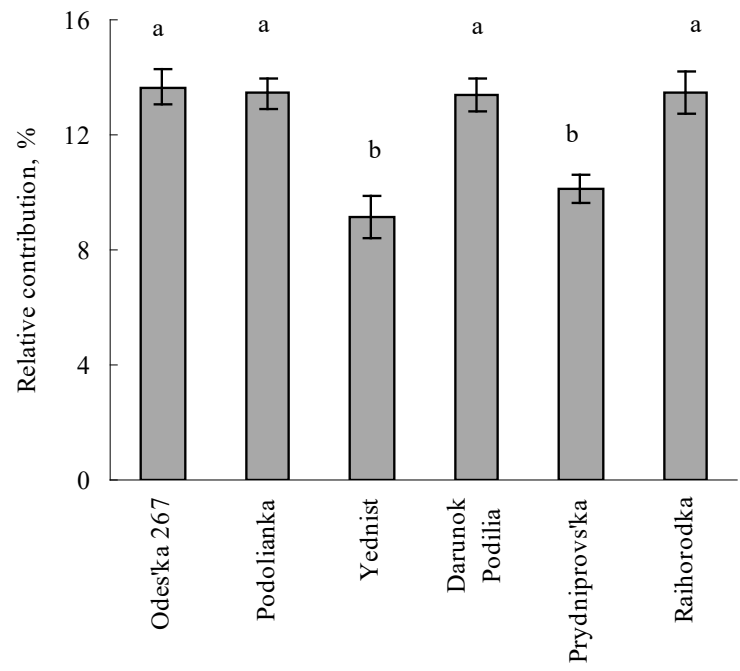

Fig. 4. Relative contribution of non-structural carbohydrates to the weight of grain of winter wheat varieties, exposed to drought and raised air temperature during the period of reproductive organs'

formation $(x \pm S E, n=25)$ : means followed the same letters are not significantly different at $\mathrm{P}<0.05$

Table 4

The yield of winter wheat varieties, released at different times $(x \pm S E, n=4)$

\begin{tabular}{lccc}
\hline \multicolumn{1}{c}{ Variety } & Year of variety release & Yield, $\mathrm{kg} / \mathrm{m}^{2}$ & $\%$ of maximal yield \\
\hline Odeska 267 & 1997 & $0.785 \pm 0.020^{\mathrm{a}}$ & 89.7 \\
Podolianka & 2003 & $0.747 \pm 0.022^{\mathrm{a}}$ & 85.4 \\
Yednist & 2008 & $0.660 \pm 0.029^{\mathrm{b}}$ & 75.4 \\
Darunok Podillia & 2013 & $0.797 \pm 0.012^{\mathrm{a}}$ & 91.1 \\
Prydniprovkka & 2014 & $0.818 \pm 0.026^{\mathrm{a}}$ & 93.5 \\
Raihorodka & 2016 & $0.875 \pm 0.021^{\mathrm{c}}$ & 100.0 \\
\hline
\end{tabular}

Note: see Table 1.

\section{Table 5}

Fisher correlation between main spike grain yield and depositing ability parameters of main shoot stem

\begin{tabular}{lccc}
\hline \multirow{2}{*}{ Parameters of depositing ability } & \multicolumn{3}{c}{ Correlation coefficient } \\
\cline { 2 - 4 } & at anthesis & $\begin{array}{c}\text { at full } \\
\text { ripeness }\end{array}$ & $\begin{array}{c}\text { with } \\
\text { difference }\end{array}$ \\
\hline Non-structural carbohydrates content & $0.64 \pm 0.38$ & $0.27 \pm 0.48$ & - \\
Amount of non-structural carbohydrates & $0.82 \pm 0.28^{*}$ & $0.52 \pm 0.43$ & $0.77 \pm 0.32$ \\
Stem dry matter weight & $0.90 \pm 0.22^{*}$ & $0.93 \pm 0.18^{*}$ & $0.70 \pm 0.36$ \\
\hline Note: ${ }^{*}$ - values are significant at $\mathrm{P}<0.05$. & &
\end{tabular}

Taking into account the results of our previous studies carried out on the same varieties of winter wheat affected by deficiency of moisture in the soil during grain filling (Morgun et al., 2018), we can state that dry weight of the stem during anthesis is closely and positively $(r=0.82$ in 2017 and $r=0.90$ in 2018) correlated with the weight of grains per ear of the main shoot over unfavourable conditions in different periods (Fig. 5). This correlation was also significant for a combined amount of the data for two years $(\mathrm{r}=0.87 \pm 0.16)$.

\section{Discussion}

Direct correlation between dry weight, as well as the amount of non-structural carbohydrates of stem of the main shoot at anthesis and the grain yield of the ear, shows that varieties with a higher dry weight and amount of water-soluble carbohydrates at this stage may be more productive. It is believed that the ability of wheat stem to accumulate carbohydrates in the pre-anthesis period affects yield, providing grain filling due to remobilization of assimilate accumulated during vegetative growth (Xue et al., 2014; Liang et al., 2017; Yáñez et al., 2017). The literature data confirm significant differences in the contribution of assimilates deposited in the stem to the grain filling at different environmental conditions or in different genotypes. Therefore, remobilisation of water-soluble carbohydrates contributed to increase in grain yield in spring wheat in favourable water conditions and different conditions of nitrogen nutrition by 8-27\% (Gebbing \& Schnyder, 1999), and for different varieties of common and durum wheat, also in conditions of sufficient water supply, by $19-54 \%$ (Ehdaie et al., 2008). Remobilization of water-soluble carbohydrates of spring wheat genotypes grown under heat stress $\left(37\right.$ and $31^{\circ} \mathrm{C}$ at day and $25^{\circ} \mathrm{C}$ at night) in a phytotron was on average $60 \%$ (Zamani et al., 2014). Remobilization efficiency of water-soluble carbohydrates from stem internodes under drought stress was $26-34 \%$ in drought-tolerant varieties and $24-53 \%$ in drought-sensitive varieties (Gupta et al., 2011).

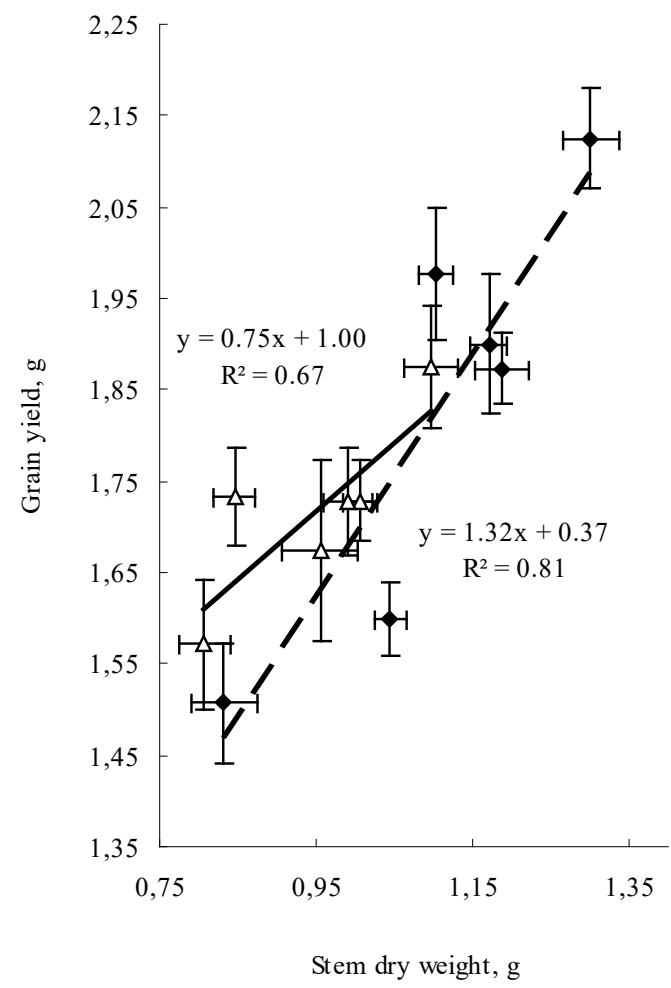

Fig. 5. The relationships between dry weight of main shoot stem at anthesis and grain yield of main shoot ear of winter wheat varieties, released at differed times: light marks - data for 2017, dark marks - for 2018; vertical and horizontal lines represent $\mathrm{x} \pm \mathrm{SE}$ of the means of the 25 replicates

However, the mechanism that regulates the contribution of nonstructural carbohydrates accumulated in the stem during pre-anthesis to the grain filling of wheat remains unclear. This may be due to the fact that the wheat stems may serve as a temporary depot of metabolites (Ruuska et al., 2006; Joudi et al., 2012). Many literature sources indicate a close positive correlation between the content of water-soluble carbohydrates in the stems and the weight of grains per ear, or mass of 1000 grains (Ehdaie et al., 2008; Nadia et al., 2017). However, there are also reports indicating absence of such a relationship. Therefore, no significant correlation between grain yield and remobilization of assimilates deposited in the stem was observed at heat stress during grain filling (Zamani et al., 2014). However, most researchers believe that water-soluble carbohydrates of the stem play an important role in grain filling efficiency, especially under unfavourable conditions; and their high content in the stems during anthesis is associated with their subsequent remobilization and use for grain filling (Ruuska et al., 2006; Joudi et al., 2012). 
Besides, it is believed that increase in the deposition of carbohydrates in the stem may be one way to maximize their transport through a constrained vascular route (Slewinski, 2012). Also, it has been shown that over the pre-anthesis period, wheat varieties with high content of non-structural carbohydrates in the stem had higher content of zeatin and zeatin riboside, hormones that stimulate the transport of nutrients into the cell (Liang et al., 2017).

Another mechanism of use of metabolites deposited in the stem during pre-anthesis is associated with its function as an alternative acceptor of the assimilates (Gupta et al., 2011; Kiriziy et al., 2014; Gonzales-Navarro et al., 2016). During the period from earing to anthesis, the photosynthetic apparatus is already completely developed and is activity functioning; at the same time, the needs of grain, the main acceptor of the assimilates, are still low. The high attracting ability of the stem during this period helps avoid the inhibition of photosynthesis by an excess of assimilates which form during the $\mathrm{CO}_{2}$ exchange process. At this period, the stem may be an alternative acceptor of photoassimilates. In particular, a direct relationship between the difference of dry weight of the stem at anthesis and full ripeness and intensity of photosynthesis in the flag leaf was determined for winter wheat varieties of Ukrainian selection (Kiriziy et al., 2014).

The closer relationship between the grain productivity and the amount of non-structural carbohydrates at anthesis than with their content in the conditions of our experiment may be related to the fact that the first parameter also includes dry mass of stem, i.e. reflects total capacity of this organ. The high correlation between the grain productivity and mass of dry matter of the stem was conditioned by the fact that in addition to carbohydrates they contain other substances (for example, nitrogen-containing) that are formed from photo-assimilates and also can be hydrolyzed.

Thus, one of the indicators associated with grain yield is dry weight of stem of the main shoot of the plants at anthesis, which characterizes the potential capasity of metabolites deposited in them. The advantage of this indicator, associated with deposition of the assimilates in the stem, is its informativeness, simple and quick determination, which is important for additional gathering or collecting of selection material in a large number of genotypes in the field. Since the dry weight of the stem of the main shoot at anthesis is closely correlated with the grain yield per ear in conditions of insufficient water supply in different periods of ontogenesis, this indicator may also be important for assessing the adaptation of wheat to certain environmental changes.

\section{Conclusions}

It was established that the grain yield of main shoot stem of winter wheat varieties was determined by dry weight of the stem at anthesis, as well as the amount of nonstructural carbohydrates at this stage. Therefore, the dry weight of the stem of the main shoot at anthesis can serve as a marker of grain yield of winter wheat. The newer varieties were significantly more productive than the older varieties by yield, weight of grains per ear, harvest index and content of nonstructural carbohydrates in the stem of the main shoot over anthesis. Their higher grain yield in drought conditions is related to the ability of the stem to deposit assimilates in the period before anthesis and a greater relative contribution of nonstructural carbohydrates accumulated in the stem during the period from anthesis to complete ripeness to the grain mass.

The publication contains the results of research carried out within the framework of the project financed by the Cabinet of Ministers of Ukraine: "Support to the development of priority areas of scientific research" (CPCS 6541230).

\section{References}

Avtaeva, T. A., Sukhodolskaya, R. A., Skripchinsky, A. V., \& Brygadyrenko, V. V. (2019). Range of Pterostichus oblongopunctatus (Coleoptera, Carabidae) in conditions of global climate change. Biosystems Diversity, 27(1), 76-84.

Blum, A. (1998). Improving wheat grain filling under stress by stem reserve mobilisation. Euphytica, 100(1), 77-83.
Ciavarella, A., Stott, P., \& Lowe, J. (2017). Early benefits of mitigation in risk of regional climate extremes. Nature Climate Change, 7, 326-330.

Dodig, D., Ranĉić, D., Vucelić Radović, B., Zorić, M., Savić, J., Kandić, V., Pećinar, I., Stanojević, S., Šeŝlija, A., Vassilev, D., \& Pekić-Quarrie, S. (2016). Response of wheat plants under post-anthesis stress induced by defoliation: II. Contribution of peduncle morpho-anatomical traits and carbon reserves to grain yield. The Journal of Agriculture Science, 155(3), 475-493.

Dong, Y., Liu, J., Zhang, Y., Geng, H., Rasheed, A., Xiao, Y., Cao, S., Fu, L., Yan, J., Wen, W., Zhang, Y., Jing, R., Xia, X., \& He, Z. (2016). Genomewide association of stem water soluble carbohydrates in bread wheat. PLoS One, 11(11), e0164293.

Ehdaie, B., Alloush, G. A., \& Waines, J. G. (2008). Genotypic variation in linear rate of grain growth and contribution of stem reserves to grain yield in wheat. Field Crops Resesearch, 106(1), 3443.

Esmaeilpour-Jahromi, M., Ahmadi, A., Lunn, J. E., Abbasi, A., Poustini, K., \& Joudi, M. (2012). Variation in grain weight among Iranian wheat cultivars: The importance of stem carbohydrate reserves in determining final grain weight under source limited conditions. Australian Journal of Crop Science, 6(11), 1508-1515.

Foulkes, M. J., Scott, R. K., \& Sylvester-Bradley, R. (2002). The ability of wheat cultivars to withhstand drought in UK conditions: Formation of grain yield. Journal of Agriculturale Science, 138, 153-169.

Gebbing, T., \& Schnyder, H. (1999). Pre-anthesis reserve utilization for protein and carbohydrate synthesis in grains of wheat. Plant Physiology, 121(3), 871-878.

Gonzalez-Navarro, O. E. S., Griffiths, G., Molero, G., Reynolds, M. P., \& Slafer, G. A. (2016). Variation in developmental patterns among elite wheat lines and relationships with yield, yield components and spike fertility. Field Crops Research, 196, 294-304.

Gupta, A., Kaur, K., \& Kaur, N. (2011). Stem reserve mobilization and sink activity in wheat under drought conditions. American Journal of Plant Science, 2(1), $70-77$.

Joudi, M., Ahmadi, A., Mohamadi, V., Abbasi, A., Vergauwen, N., Mohammadi, H., \& Van den Enge, W. (2012). Comparison of fructan dynamics in two wheat cultivars with different capacities of accumulation and remobilization under drought stress. Physiologia Plantarum, 144(1), 1-12.

Kiriziy, D. A., Stasik, O. O., Priadkina, G. A., \& Shadchina, T. M. (2014). Fotosintez: Assimilyatsiya $\mathrm{CO}_{2}$ i mekhanizmy yeye regulyatsii [Photosynthesis: $\mathrm{CO}_{2}$ assimilation and mechanisms of its regulation]. Logos, Kyiv (in Russian).

Li, W., Zhang, B., Li, R., Chang, X., \& Jing, R. (2015). Favorable alleles for stem water-soluble carbohydrates identified by association analysis contribute to grain weight under drought stress conditions in wheat. PloS One, 10(3), e119438.

Liang, W., Znang, Z., Wen, X., Liao, Y., \& Liu, Y. (2017). Effect of non-structural carbohydrate accumulation in the stem pre-anthesis on grain filling of wheat inferior grain. Field Crop Research, 211, 66-76.

Lobell, D. B., Schlenker, W., \& Costa-Roberts, J. (2011). Climate trends and global crop production since 1980. Science, 333(6042), 616-620.

Ma, J., Huang, G.-B., Yang, D.-L., \& Chai, Q. (2014). Dry matter remobilization and compensatory effects in various internodes of spring wheat under water stress. Crop Science, 54, 331-339.

Morgun, V. V., Priadkina, G. A., \& Zborovska, O. V. (2018). Dependence of main shoot ear grain from stem deposited ability of winter wheat varieties. Ukrainian Journal of Ecology, 8(3), 113-118.

Morgun, V. V., Sanin, Y. V., \& Schwartau, V. V. (2015). Sorty ta tekhnolohiyi vyroshchuvannya vysokykh urozhayiv ozymoyi pshenytsi. Klub 100 tsentneriv [Varieties and growing technologies of high winter wheat crops. The club of 10 tons]. Lohos, Kyiv (in Ukrainian).

Morgun, V. V., Schwartau, V. V., \& Kiriziy, D. A. (2008). Fiziolohichni osnovy otrymannya vysokykh urozhayiv ozymoyi pshenytsi [Physiological basis for obtain high yields of wheat]. Fyzyolohyya y byokhymyya kulturnyh rastenyy, 40(6), 463-469 (in Ukrainian).

Nadia, K., Chang, X., \& Jing, R. (2017). Genetic dissection of stem water-soluble carbohydrates and agronomic traits in wheat under different water regimes. Journal of Agricultural Science, 9(3), 42-58.

Olsovska, K., Kovar, M., Brestic, M., Zivcak, M., Slamka, P., \& Shao, H. B. (2016). Genotypically identifying wheat mesophyll conductance regulation under progressive drought stress. Frontiers in Plant Science, $2016(7), 1111$.

Ouyang, W., Struik, P. C., Yin, X., \& Yang, J. (2017). Stomatal conductance, mesophyll conductance, and transpiration efficiency in relation to leaf anato$\mathrm{my}$ in rice and wheat genotypes under drought. Journal of Experimental Botany, 68, 5191-5205.

Ovenden, B., Milgate, A., Lisle, C., Wade, L. J., Rebetzke, G. J., \& Holland, J. B. (2017). Selection for water-soluble carbohydrate accumulation and investigation of genetic $\times$ environment interactions in an elite wheat breeding population. Theoretical and Applied Genetics, 130(11), 2445-2461.

Papakosta, D. K., \& Gagianas, A. A. (1991). Nitrogen and dry matter accumulation, remobization and loses for Mediterranian wheat during grain filling. Agronomy Journal, 83(5), 864-870. 
Reynolds, M., Tattaris, M., Cossani, C. M., Ellis, M., Yamaguchi-Shinozaki, K. \& Pierre, C. S. (2015). Exploring genetic resources to increase adaptation of wheat to climate change. In: Ogihara, Y., Takumi, S., \& Handa, H. (eds.) Advances in wheat genetics: From genome to field. Proceedings of the 12th International Wheat Genetics Symposium. Springer, Tokyo. Pp. 355-368.

Ruuska, A. C., Rebetzke, G. J., van Herwaarden, A. F., Richadrs, R. A., Fettell, N. A Tabe, L., \& Jenkins, C. L. D. (2006). Genotypic variation in water-soluble carbohydrate accumulation in wheat. Functional Plant Biology, 33, 799-809.

Saeidi, M., Moradi, F., \& Jalali-Honarmand, S. (2012). The effect of post anthesis source limitation treatments on wheat cultivars under water deficit. Australian Journal of Crop Science, 6(7), 1179-1187.

Slewinski, T. L. (2012). Non-structural carbohydrate partitioning in grass stems: A target to increase yield stability, stress tolerance, and biofuel production. Journal of Experimental Botany, 63, 4647-4670.

Xue, Q., Rudd, C., Liu, S., Jessup, K. E., Devkota, R. N., \& Mahan, J. R. (2014). Yield determination and water-use efficiency of wheat under water-limited condition in the U.S. Southern High Plains. Crop Science, 54, $34-47$.

Yan, W., Zhong, Y., \& Shangguan, Z. (2016). A meta-analysis of leaf gas exchange and water status responses to drought. Scientific Reports, 6, 20917.
Yáñez, A., Tapia, G., Guerra, F., \& del Pozo, A. (2017). Stem carbohydrate dynamics and expression of genes involved in fructan accumulation and remobilization during grain grown in wheat (Triticum aestivum L.) genotypes with contrasting tolerance to water stress. PLoS One, 12(5), e0177667.

Yermakov, A. I. (Ed.). (1972). Metody biokhimicheskogo analiza rasteniy [Methods of plants biochemical analysis]. Kolos, Leningrad (in Russian).

Zadoks, J. C., Chang, T. T., \& Konzak, C. F. (1974). A decimal code for the growth stages of cereals. Weed Research, 14, 415-421.

Zamani, M. M., Nabipour, M., \& Meskarbashee, M. (2014). Stem water soluble carbohydrate remobilization in wheat under heat stress during the grain filling. International Journal of Agriculture and Biology, 16, 401-405.

Zhang, J., Xu, Y., Chen, W., Dell, B., Vergauwen, R., Biddulph, B., Khan, N., Luo, H., Appels, R., \& Van den Enge, W. (2015). A wheat 1-FEH w3 variant underlies enzyme activity for stem WSC remobilization to grain under drought. New Phytologist, 205, 293-305.

Zhang, J., Zhang, S., Cheng, M., Jiang, H., Zhang, X., Peng, C., Lu, X., Zhang, M., \& Jin, J. (2018). Effect of drought on agronomic traits of rice and wheat: A meta-analysis. International Journal of Environmental Research and Public Health, 15(5), 839 . 